\title{
Analisis Kesediaan Konsumen Membayar Durian di Gerai Ucok Durian Medan
}

\author{
Analysis of Consumer' Willingness to Pay for Durian at Ucok Durian Medan Outlet
}

\author{
Chintia Damayani.P ${ }^{1}$, Titik Ekowati ${ }^{2}$, Edy Prasetyo ${ }^{3}$ \\ ${ }^{123}$ Program Studi Agribisnis, Fakultas Peternakan dan Pertanian Universitas Diponegoro \\ Kampus Drh.R. Soeyono Koesoemowardojo, Tembalang, Semarang, 50275 \\ Email : chintyadamayani@gmail.com
}

Article Submitted : 09-06-2021

Article Accepted : 17-12-2021

\begin{abstract}
Durian is a plant that isn't always available at all times or called local durian. This condition encourages Ucok Durian outlets to always provide good quality durian. This study aims to describe the characteristic of consumers durian, analyze the average value of maximum that consumers are willing to pay, and determine the factors that influence consumers' Willingness To Pay (WTP). The research method is the survey method, conducted at the Ucok Durian Medan outlet. The sampling method used accidental purposive sampling and the determination number of samples using quota sampling of 80 respondents. Data analysis used descriptive analysis to explain consumer characteristics, Contingent Valuation Method (CVM) analysis to calculate the value consumers WTP for durian, and logistic regression analysis to analyze the factors that influence consumers' WTP for durian. The results showed that most of the consumers is male (72.6\%), 17-25 years old (38.8\%), married status (73.8\%), last education is Diploma and S1 (56.2\%), the number of family members is 4-6 people (65\%), formal work (91.2\%) and income> Rp 4,000,000 - Rp 7,000.000/month (38.8\%). As many as $86.25 \%$ of respondents are willing to pay for durian which is more expensive than the normal price. The average value of the consumer's WTP for durian, respectively, is $R p$ 50,000 and $R p$ 75,000, amounting to $R p$ 53,284.31 and $R p$ $75,625 /$ piece, with a proportion of $6.57 \%$ and $0.83 \%$ of the current price. The factors that influence consumers' WTP for durian are jobs, price, product quality, and lifestyle.
\end{abstract}

Keywords: consumer characteristic, durian, factors, WTP

\section{PENDAHULUAN}

Komoditas hortikultura merupakan bagian dari sektor pertanian yang mempunyai nilai jual yang tinggi, keragaman jenis, ketersediaan sumberdaya lahan dan teknologi, serta berpotensi terhadap serapan pasar nasional ataupun internasional (Direktorat Jendral Hortikultura, 2013). Serapan pasar komoditas hortikultura seperti buah-buahan berkontribusi terhadap PDB Indonesia. Nilai PDB buah-buahan tercatat Rp 51,217 milyar atau sekitar $4,57 \%$, artinya buah-buahan memiliki kedudukan lebih tinggi dalam menyumbang PDB dibandingkan dengan sayuran dan obat-obatan (Kementerian Pertanian, 2015). Buah-buahan yang memiliki keunggulan secara nasional yaitu jeruk, mangga, manggis, salak, pisang dan durian (Direktorat Jendral Hortikultura, 2013).

Durian merupakan buah tropis yang hanya dipanen sekali dalam setahun, yang berarti durian tidak tersedia setiap waktu, sehingga keinginan konsumen untuk mengkonsumsi durian tidak terpenuhi. Selain itu, durian di Indonesia menghadapi masalah pada kualitas buah. Beberapa kasus yang menyebabkan kualitas durian lokal kurang dipercaya oleh konsumen, karena buah durian yang mengkal artinya durian yang belum sepenuhnya mateng sudah dijual, daging durian yang lunak dan berair, serta sebagian daging durian mengering. Mayoritas penjual durian memasarkan durian hanya dipinggir jalan, dan dilakukan ketika musim durian saja, padahal keinginan konsumen untuk mengkonsumsi durian tidak hanya waktu musim panen saja, melainkan tersedianya durian setiap waktu.

Gerai Ucok Durian merupakan gerai yang menyediakan durian disetiap waktu, dengan kualitas durian yang baik, memberikan garansi dapat menukar durian jika rasa durian tidak sesuai dengan keinginan konsumen. Gerai Ucok Durian menyediakan tempat makan durian yang sesuai dengan gaya hidup konsumen. Menurut Yuliati dan Rahmah (2019) perilaku seseorang dapat dilihat dari gaya hidup, dengan cara melihat bagaimana seseorang tersebut mengunakan uang dan memanfaatkan waktunya dengan baik. Dengan demikian, banyak konsumen yang berkunjung di Gerai Ucok Durian untuk menikmati makan durian. Kunjungan konsumen di Gerai Ucok Durian bisa mencapai 200-300 orang perharinya, bahkan lebih dengan volume penjualan durian perharinya 2.0003.000 buah.

Harga durian yang telah di tetapkan di Gerai Ucok Durian berkisar Rp 50.000 sampai $\mathrm{Rp} 100.000$ perbuahnya, tergantung besar kecilnya durian tersebut. Harga tersebut relatif lebih murah dibandingkan dengan harga durian di usaha sejenis ataupun durian impor. Meskipun demikian, Gerai Ucok Durian tetap memberikan kulitas durian yang nikmat dan mementingkan kepuasan konsumen. 
Sehingga banyak konsumen yang berkunjung dengan berbagai kalangan sesuai dengan karakteritiknya.

Penelitian terdahulu telah banyak melakukan kajian mengenai kesediaan konsumen membayar terkait produk pertanian. Rostiati (2015) melakukan penelitian WTP terhadap jeruk impor. Variabel yang berpengaruh secara signifikan adalah pendapatan, jumlah anggota keluarga, kualitas harga dan bidding price. Selain itu penelitian oleh (Fajria et al.,2020) terakait Willingness to Pay menggunakan variabel usia, jenis kelamin, status pernikahan, pendidikan, pekerjaan, pendapatan, harga dan kualitas. Dengan demikian peneliti mencoba untuk melakukan penelitian terkait kesediaan konsumen membayar durian di Gerai Ucok Durian Medan dengan menggunakan variabel usia, jumlah anggota keluarga, pekerjaan, pendapatan, harga, kualitas produk dan gaya hidup.

Tujuan dari penelitian ini adalah 1) mendeskripsikan karakteristik konsumen durian di Gerai Ucok Durian. 2) menganalisis nilai rata-rata maksimum kesediaan konsumen membayar durian di Gerai Ucok Durian. 3) menganalisis pengaruh faktor usia, jumlah anggota keluarga, pekerjaan, pendapatan, harga, kualitas produk dan gaya hidup terhadap kesediaan membayar konsumen terhadap durian.

\section{BAHAN DAN METODE}

\section{Metode Penelitian}

Penelitian dilakukan di Gerai Ucok Durian Medan, dilaksanakan pada 27 Februari - 10 Maret 2021. Metode penelitian yang digunakan adalah metode survei, dengan metode pengumpulan data melalui wawancara, observasi dan dokumentasi. Metode penentuan sampel yaitu accidental purposive sampling. Teknik yang digunakan untuk menentukan jumlah sampel adalah quota sampling. Teknik ini dipilih karena jumlah populasi konsumen tidak diketahui secara pasti, sehingga sampel yang digunakan dalam penelitian ini sebanyak 80 responden.

\section{Analisis Data}

Analisis data pada penelitian ini terdiri dari analisis deskriptif, analisis contingent valuation methode (CVM) dan analisis regresi logistik. Analisis deksriptif digunakan untuk menganalisis tujuan penelitian pertama yaitu karakteristik konsumen durian di Gerai Ucok Durian. Analisis (CVM) digunakan untuk menganalisis nilai ratarata kesediaan membayar maksimum konsumen durian di Gerai Ucok Durian. Metode CVM yang digunakan pada penelitian ini adalah metode tawarmenawar (Bidding Game). Adapun tahapan dari analisis CVM adalah membuat pasar hipotesis, menentukan nilai Bids, menghitung rata-rata willingness to pay, mengestimasi kurva WTP dan mengagregatkan data (Hanley dan Barbier, 2009). Analisis regresi logistik merupakan uji yang dilakukan untuk menganalisis faktor-faktor yang berpengaruh terhadap kesediaan konsumen membayar durian. Uji regresi logistik mengkaji hubungan variabel independen $(\mathrm{x})$ terhadap variabel dependen (y) melalui model persamaan matematis tertentu. Persamaan regresi logistik pada penelitian ini adalah :

$\begin{aligned} \mathrm{Y}=\mathrm{In}\left(\frac{1}{1-p}\right)= & \mathrm{b}_{0}+\mathrm{b}_{1} \mathrm{X}_{1}+\mathrm{b}_{2} \mathrm{X}_{2}+\mathrm{b}_{3} \mathrm{X}_{3}+\mathrm{b}_{4} \mathrm{X}_{4}+\mathrm{b}_{5} \mathrm{X}_{5}+\mathrm{b}_{6} \mathrm{X}_{6} \\ & +\mathrm{b}_{7} \mathrm{X}_{7}+\mathrm{e}\end{aligned}$

Keterangan :

$\mathrm{Y}=$ Kesediaan Membayar Konsumen Ya (1) atau Tidak (0)

$\mathrm{b}_{0}=$ Konstanta Regresi

$\mathrm{X}_{1}=$ Usia (tahun)

$\mathrm{X}_{2}=$ Jumlah Anggota Keluarga (Orang)

$\mathrm{X}_{3}=$ Pekerjaan

$\mathrm{X}_{4}=$ Pendapatan $(\mathrm{Rp} /$ Bulan $)$

$\mathrm{X}_{5}=$ Harga $(\mathrm{Rp})$

$\mathrm{X}_{6}=$ Kualitas Produk (skor)

$\mathrm{X}_{7}=$ Gaya hidup (skor)

$e=$ ketetapan

Pengujian parameter yang digunakan dalam analisis regresi logistik yaitu uji $G$ dan uji Wald. Sedangkan rasio odd digunakan untuk interpretasi persamaan regresi logistik.

\section{HASIL DAN PEMBAHASAN}

\section{Karakteristik Umum Responden}

Karakteristik responden durian di Gerai Ucok Durian didominasi oleh laki-laki karena responden laki-laki lebih sering berkumpul. Pernyataan ini didukung oleh Nurcahyo dan Khasanah (2016) bahwa konsumen laki-laki lebih mendominasi karena lebih sering melakukan aktivitas diluar dan ngumpul di cafe. berusia $17-25$, status pernikahan sudah menikah. Latar belakang pendidikan responden Diploma dan Strata 1, memiliki jumlah anggota keluarga $4-6$ orang, memiliki pekerjaan sebagai pegawai swasta. Jumlah pendapatan $>\mathrm{Rp}$ 4.000.000 - Rp 7.000.000 per bulan, membeli durian dengan harga Rp 50.000 per buah. Konsumen memberikan penilaian tinggi terhadap kualitas produk dan memberikan penilaian sedang terhadap gaya hidup konsumen di Gerai Ucok Durian

\section{Kesediaan Membayar}

Sebanyak 69 dari 80 responden bersedia membayar lebih untuk memperoleh durian dan 11 responden tidak bersedia membayar. Alasan konsumen tidak bersedia membayar karena harga 
dengan kualitas sudah sesuai. Pernyataan ini didukung oleh Bilgies (2016) konsumen tidak hanya mempertimbangkan kualitasnya saja, tetapi juga memikirkan kelayakan harga. Responden tetap bersedia membayar karena Gerai Ucok Durian selalu mementingkan kualitas durian agar konsumen merasa puas. Pernyataan ini didukung oleh Maria dan Anshori (2013) produk yang dirasa konsumen memberikan kepuasan sendiri akan mempengaruhi kesediaan membayar konsumen lebih.

Responden yang bersedia membayar lebih durian, sebagian besar didominasi oleh konsumen laki-laki, berusia 17 - 25 tahun, memiliki pekerjaan formal. Rata-rata responde sudah menikah, berpendidikan Diploma dan S1, jumlah anggota keluarga $4-6$ orang dan pendapatan $\mathrm{Rp} 1.000 .000$ - 4.000.000,- per bulan. Konsumen membeli durian dengan harga Rp 50.000, memberikan skor penilaian terhadap kualitas durian dan gaya hidup 28 dan 14. Peneliti memberikan tawaran terhadap durian di Gerai Ucok Durian, yaitu 5\% sampai 20\% dan responden memilih kesediaan membayar yang berbeda-beda, yang disajikan pada Tabel 2 .

Tabel 1. Jumlah Responden yang Bersedia Membayar Lebih

\begin{tabular}{cc}
\hline \hline Kesediaan Membayar & Jumlah Responden \\
\hline$---\%---$ & -- org--- \\
5 & 54 \\
10 & 11 \\
15 & 3 \\
20 & 1 \\
\hline
\end{tabular}

Tabel 1. menunjukkan sebanyak bersedia 54 responden bersedia membayar 5\%, 11 responden bersedia membayar $10 \%, 3$ responden bersedia membayar $15 \%, 1$ responden bersedia membayar $20 \%$ lebih tinggi dari harga sebelumnya. Berdasarkan pernyataan tersebut sebagian besar responden bersedia membayar 5\% untuk produk durian, sedangkan responden yang paling sedikit hanya bersedia membayar 20\%. Hal ini karena responden Gerai Ucok Durian telah setia terhadap durian. Pernyataan ini didukung oleh Sari et al. (2020) konsumen tetap melakukan pembelian produk meskipun harga produk tersebut mengalami kenaikan, karena konsumen telah terikat dengan produk tersebut.

\section{Perhitungan rata-rata maksimum kesediaan konsumen membayar durian}

Hasil rata-rata maksimum nilai kesediaan konsumen membayar durian berbeda karena terdapat perbedaan harga durian. Nilai rata-rata maksimum WTP durian dengan harga Rp 50.000,sebesar Rp 53.284,31 per buah, terjadi kenaikan harga antara nilai rata-rata WTP durian dengan harga awal sebesar $6,57 \%$. Nilai rata-rata maksimum WTP durian dengan harga Rp 75.000,- sebesar Rp 75.625,- per buah, terjadi kenaikan harga antara nilai rata-rata WTP durian dengan harga awal sebesar $0,83 \%$. Hasil ini sesuai dengan pendapat Maria dan Anshori (2013) menyatakan bahwa konsumen akan bersedia membayar lebih apabila produk yang dibeli mempunyai kualitas dan memberikan kepuasan kepada konsumen.

\section{Kurva WTP Durian}

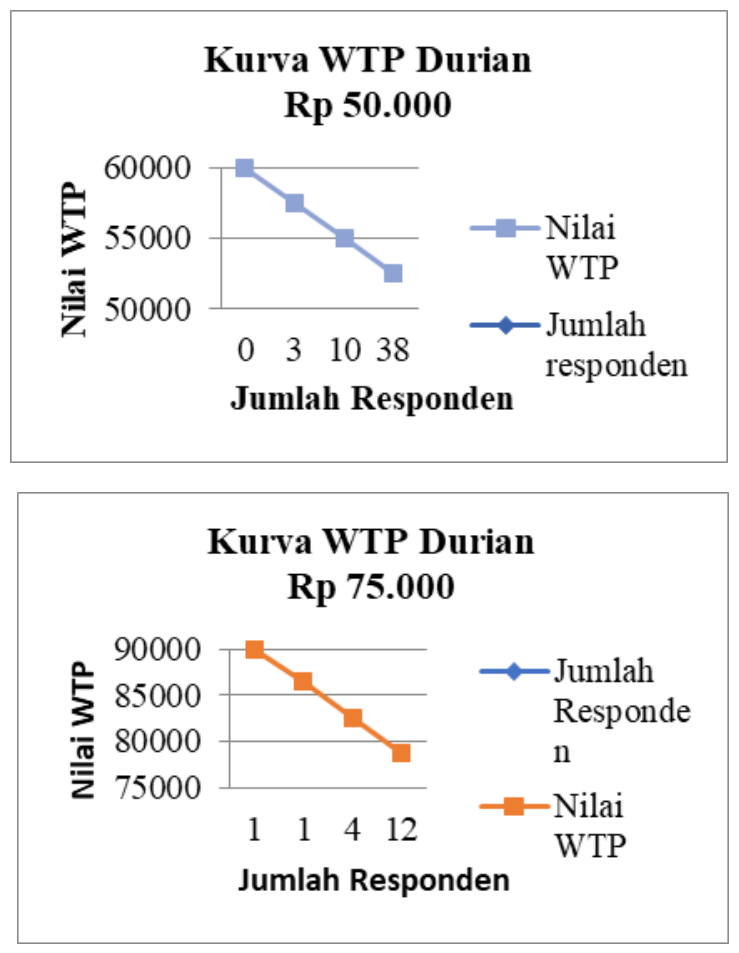

Ilustrasi 1. Kurva WTP Durian.

Berdasarkan Ilustrasi 1. kurva WTP durian harga Rp 50.000,- , sebanyak 38 responden bersedia membayar $\mathrm{Rp}$ 52.500, 10 responden bersedia membayar $\mathrm{Rp} 55.000$, dan 3 responden bersedia membayar Rp 57.500. Kurva WTP durian harga Rp 75.000,- diperoleh hasil sebanyak 12 reponden bersedia membayar $\mathrm{Rp} 78.750,4$ responden bersedia membayar $\mathrm{Rp} 82.500,1$ responden bersedia membayar Rp 86.500 dan Rp 90.000.

Kurva WTP durian tersebut menunjukkan bahwa jumlah konsumen yang bersedia membayar lebih durian semakin sedikit, karena nilai WTP durian juga semakin meningkat. Hal ini sependapat dengan Sari et al. (2020) kemampuan konsumen untuk membayar produk akan semakin berkurang apabila harga produk tersebut semakin mahal.

\section{Agregasi WTP Durian}

Hasil agregasi WTP durian dengan harga Rp 50.000,- sebesar Rp 2.717.500,- dan untuk agregasi WTP durian dengan harga Rp 75.000,- sebesar Rp 1.361.250,-. Hasil tersebut menunjukkan penerimaan yang diperoleh Gerai Ucok Durian apabila menggunakan harga yang bersedia dibayarkan oleh konsumen. Hal ini sependapat 
dengan Habib dan Kuntandi (2020) fungsi dilakukannya perhitungan agregasi nilai WTP untuk melihat potensi finansial yang diperoleh setelah melakukan pelelangan harga dengan konsumen.

Tingginya agregasi nilai WTP durian dengan harga Rp 50.000,- karena keinginan konsumen untuk membeli dan menikmati durian di lapangan cukup tinggi. Harga durian di Gerai Ucok Durian juga terjangkau dan sudah memberikan kenyaman untuk mengumpul bersama. Maulana (2016) apabila suatu produk memberikan kualitas dan kenyaman baik dari segi pelayanan, maka konsumen akan bersedia melakukan pembelian.

\section{Faktor-faktor yang mempengaruhi kesediaan konsumen membayar durian}

Berdasarkan pengujian Hosmer and Lemeshow Test diperoleh nilai chi square sebesar 6,272< Tabel 3. Hasil Uji Wald

\begin{tabular}{lcccrl}
\hline \hline Variabel & Koef(B) & Wald & P value $($ sig) & Odds Ratio & Kesimpulan \\
\hline Usia & $-0,164$ & 0,395 & 0,679 & 0,849 & Tidak Signifikan \\
Jumlah Angggota Keluarga & 0,570 & 0,838 & 0,496 & 1,768 & Tidak Signifikan \\
Pekerjaan & 2,742 & 1,368 & 0,045 & 15,511 & Signifikan \\
Pendapatan & $-0,571$ & 0.529 & 0,280 & 0,565 & Tidak Signifikan \\
Harga & $-2,100$ & 0,962 & 0,029 & 0,122 & Signifikan \\
Kualitas Produk & 0,311 & 0,156 & 0,046 & 1,365 & Signifikan \\
Gaya Hidup & 0,332 & 0,167 & 0,047 & 1,394 & Signifikan \\
\hline
\end{tabular}

Berdasarkan hasil Uji Wald pada Tabel 9. diperoleh hasil bahwa variabel pekerjaan, harga, kualitas produk dan gaya hidup berpengaruh nyata terhadap variabel dependen, karena memiliki nilai signifikan $<0,05$.

Variabel usia (X1) memiliki nilai signifikan 0,689. Nilai tersebut lebih besar dari taraf nyata $(0,689>0,05)$, artinya kesediaan konsumen untuk membayar lebih tinggi untuk memperoleh durian tidak dipengaruhi oleh usia. Usia konsumen tidak menjadi penghalang untuk tetap melakukan pembelian durian, meskipun makan durian sedikit, Gerai Ucok Durian tetap cocok untuk berkumpul bersama rekan kerja atau keluarga. Pernyataan ini sesuai dengan Damanik (2019) bahwa meskipun umur usia konsumen > 20 tahun konsumen tersebut tetap melakukan pembelian dan bersedia membayar lebih.

Variabel jumlah anggota keluarga (X2) memiliki nilai signifikan yaitu 0,496 . Nilai tersebut lebih besar dari taraf nyata $(0,496>0,05)$, artinya kesediaan konsumen membayar durian, tidak dipengaruhi oleh jumlah anggota keluarga. Hal ini dikarenakan banyak atau sedikitnya jumlah anggota keluarga tidak menjadi pertimbangan konsumen untuk membayar lebih. Sari et al. (2020) jumlah anggota keluarga tidak berpengaruh terhadap kesediaan membayar karena banyaknya jumlah anggota dalam keluarga tidak dijadikan pertimbangan bagi konsumen.
12.591 (nilai chi-square tabel) dan nilai signifikan $0,617>0,05$. Hasil tersebut menunjukkan Ho diterima yang berarti model tersebut layak dan dapat diprediksi.

Uji Nagalkerke $R$ Ssquare dilakukan untuk menganalisis kemampuan variabel independen menjelaskan variabel dependen. Berdasarkan output Nagalkerke $R$ Ssquare diperoleh hasil 0,323. Nilai 0,323 atau $32,3 \%$ menjelaskan bahwa variabel independen mampu menjelaskan variabel dependen sebesar $32,3 \%$ dan sisanya dijelaskan oleh variabel lain.

Berdasarkan hasil uji Uji G atau Omnibus Test of Model Coeffients diperoleh nilai chi square sebesar 15,688>14,0671 (nilai chi square df 6) Nilai signifikansi sebesar $0,028<0,05$, artinya $\mathrm{Hl}$ diterima dan terdapat minimal satu variabel independen yang mempengaruhi variabel dependen
Variabel pekerjaan (X3) memiliki nilai signifikansi yaitu sebesar 0,045 . Nilai tersebut lebih kecil dari taraf nyata $(0,045<0,05)$, artinya

kesediaan konsumen membayar durian dipengaruhi oleh pekerjaan. Rata-rata konsumen yang melakukan pembelian durian memiliki pekerjaan formal, artinya pekerjaan formal mempengaruhi konsumen untuk bersedia membayar lebih durian. Fajria et al. (2020) menegaskan bahwa pekerjaan mempengaruhi kesediaan konsumen membayar produk, karena konsumen yang memiliki pekerjaan akan lebih mudah mengambil keputusan.

Variabel pendapatan (X4) memiliki nilai dari taraf nyata $(0,280>0,05)$, artinya variabel pendapatan tidak berpengaruh secara parsial terhadap kesediaan membayar durian di Gerai Ucok Durian. Hal ini dikarenakan besar kecilnya pendapatan konsumen Gerai Ucok Durian, tetap melakukan pembelian karena kualitas durian yang dirasa memberikan kepuasan. Hal sependapat dengan Bahri (2018) konsumen yang telah merasakan kepuasan terhadap suatu produk akan melakukan pembelian ulang.

Variabel harga (X5) memiliki nilai signifikansi yaitu 0,029 . Nilai tersebut lebih kecil dari taraf nyata yang telah ditetapkan $(0,029<0,05)$, artinya variabel harga secara parsial mempengaruhi kesediaan konsumen membayar durian di Gerai Ucok Durian. Hal ini dikarenakan harga durian di Ucok Durian termasuk murah dan masih bisa signifikansi yaitu 0,280 . Nilai tersebut lebih besar 
dijangkau oleh konsumen dibandingkan durian di tempat lain. Harga berkaitan erat dengan keputusan konsumen dalam membeli. Pernyataan ini didukung oleh Zulaicha dan Irawati (2016) menyatakan bahwa harga mempengaruhi keputusan konsumen, dengan harga terjangkau akan membuat konsumen menjadi pelanggan tetap.

Variabel kualitas produk (X6) memiliki nilai signifikansi 0,046 . Nilai tersebut lebih kecil dari taraf nyata $(0,046<0,05)$, artinya variabel kualitas produk secara parsial mempengaruhi kesediaan konsumen membayar durian di Gerai Ucok Durian. Hal ini dikarenakan Gerai Ucok Durian selalu mementingkan kulitas durian seperti rasa, tempat makan durian yang bersih, dan durian yang selalu ada disetiap waktu. Maria dan Anshori (2013) bahwa konsumen akan bersedia membayar lebih apabila produk yang dikonsumsi memilki kualitas yang memuaskan konsumen.

Variabel gaya hidup (X7) memiliki nilai signifikansi 0,047 . Nilai tersebut lebih kecil dari taraf nyata yaitu $(0,047<0,05)$, artinya variabel gaya hidup berpengaruh secara parsial terhadap kesediaan konsumen membayar durian. Gaya hidup konsumen yang membeli atau makan durian adalah konsumen yang menghabiskan sebagian waktunya diluar bersama keluarga atau rekan kerja. Pernyataan ini didukung oleh Hidayatullah dan Zahara (2020) gaya hidup konsumen lebih sering menghabiskan waktu dengan mencerminkan pola konsumsinya dan memanfaatkan sejumlah uang.

\section{Kesimpulan}

Karakteristik konsumen durian di Gerai Ucok Durian didominasi oleh laki-laki, berusia $17-25$ tahun dan sudah menikah. Latar belakang pendidikan konsumen yaitu Diploma dan Strata, jumlah anggota keluarga $4-6$ orang, memiliki pekejaan formal. Jumlah pendapatan $>\mathrm{Rp}$ 4.000.000 - Rp 7.000.000 per bulan , membeli durian dengan harga $\mathrm{Rp} 50.000$ per buah. Konsumen memberikan penilaian tinggi terhadap kualitas durian. Dan memberikan penilaian sedang terhadap gaya hidup konsumen di Gerai Ucok Durian.

Nilai rata-rata kesediaan konsumen membayar durian di Gerai Ucok Durian untuk harga Rp 50.000 per buah sebesar Rp 53.284,3. Sedangkan harga Rp 75.000 per buah sebesar Rp 75.625. Persentase kenaikan harga masing-masing sebesar $6,57 \%$ dan $0,83 \%$ dari harga saat ini.

Faktor usia, jumlah anggota keluarga, pendapatan, pekerjaan, harga, kualitas produk dan gaya hidup secara serempak berpengaruh secara nyata terhadap kesediaaan membayar durian. Sedangkan secara pasial faktor pekerjaan, harga, kualitas produk dan gaya hidup berpengaruh terhadap kesediaan membayar durian di Gerai Ucok Durian.

\section{UCAPAN TERIMA KASIH}

Ucapan terima kasih dipersembahkan kepada :

1. Dr. Ir. Titik Ekowati, M.Sc.

2. Dr. Ir. Edy Prasetyo, M.S.

3. Bapak dan Ibu dosen Prodi Agribisnis

4. Serta semua rekan dan pihak atas bimbingan, arahan dan dukungan dalam penelitian ini

\section{DAFTAR PUSTAKA}

Bahri. 2018. Keputusan pembelian dan kepuasan konsumen dipengaruhi variabel lokasi, pelayanan, kualitas produk, nilai emosional, dan disain interior yang berdampak pada tingkat pembelian. J. Maksipreneur. 8 (1): 60 80 .

Bilgies. A.F. 2016. Peran kualitas produk, harga dan kualitas layanan terhadap kepuasan pelanggan billagio skincare clinic. J. Ekonomi Universitas Kadiri. 1(1): 78 - 90

Damanik, D. 2019. Willingness to pay (wtp) pengunjung museum Simalungun di Kota Pematang Siantar. J. IKRA-ITH Ekonomika. 2 (3): $9-16$.

Direktorat Jendral Hortikultura. 2013. Peningkatan Produksi, Produktivitas dan Mutu Produk Hortikultura Berkelanjutan Tahun 2014. Jakarta.

Fajria, F., D. Ethika dan D. Kusnaman. 2020. Analisis kesediaan membayar (willingness to pay) konsumen terhadap sayuran organik di pasar modern Purwokerto dan faktor yang memengaruhi. J. SEPA. 17 (1): 40 - 48.

Habib, E. A dan E. B. Kuntandi. 2020. Analisis willingness to pay beras organik aromatik "botanik" gapoktan al-barokah di Kabupaten Bondowoso. J. Sosial Ekonomi Pertanian. 13(1): 38-52.

Hanley N, Barbier E.B. 2009. Pricing Nature : Cost-Benefit Analysis and the Environment. England: Edward Elger Publishing Limited.

Hidayatullah, G. F. F dan Z. Zahara. 2020. Peran gaya hidup terhadap keputusan pembelian di cafe orangae puncak padanjese. J. Ilmu Manajemen. 6 (1): $069-077$.

Kementerian Pertanian. 2015. Analisis PDB Sektor Pertanian Tahun 2015. Pusat Data dan Sistem Informasi Pertanian Sekretariat Jenderal Kementerian Pertanian. 
Maria, M. dan M. Y. Anshori. 2013. Pengaruh kualitas produk dan kualitas layanan terhadap kepuasan konsumen king cake. J. Manajemen Teori dan Terapan. 6 (1): $1-9$.

Maulana, A.S. 2016. Pengaruh kualitas pelayanan dan harga terhadap kepuasan pelanggan PT. TO. J. Ekonomi 7(2): $113-125$.

Nurcahyo , B. H. dan I. Khasanah. 2016. Analisis pengaruh persepsi harga, kualitas pelayanan, lokasi, dan word of mouth terhadap keputusan pembelian (Studi pada taman Joglo Cafe Semarang). J. Akuntansi. 5(3): 1-16.

Rostiati, N. 2015. Willingness to pay konsumen terhadap buah jeruk impor (perspektif konvensional vs islam). J. Economica Sharia. 1(1): $23-38$.

Sari, D. K., T. Ekowati dan A. Setiadi. 2020. Analisis kesediaan konsumen untuk membayar produk tempe hygiene rumah kedelai Grobogan di Kabupaten Grobogan. J. Sosial Ekonomi Pertanian. 13(2): 145-158.

Yuliati, A. L dan Rahmah, A. 2019. Pengaruh store atmospere dan gaya hidup terhadap keputusan pembelian konsumen di Matahari Department Store. e-Proceeding of Management. 6(3): $6254-6259$.

.Zulaicha, S dan R. Irawati. 2016. Pengaruh produk dan harga terhadap keputusan pembelian konsumen di morning bakery Batam. J. Inovasi dan Bisnis. 4(2): 125-136. 